\title{
Analysis of The Nurses Service in Preventing Stunting at UPT Puskesmas Astana Anyar Bandung
}

\author{
Afrizal Hendra \\ Universitas Negeri Jakarta \\ Email : afrizalhendra_7647130408@mhs.unj.ac.id \\ Ma'ruf Akbar \\ Universitas Negeri Jakarta \\ Email : marufakbar@unj.ac.id \\ Rd. Tuti Sariwulan \\ Universitas Negeri Jakarta \\ Email : tuty.wulan@unj.ac.id
}

\begin{abstract}
This study focuses on the nurses' service in preventing stunting at UPT Puskesmas Astana Anyar, Bandung. Puskesmas is an institution that provides health services to the community but the quality and standards are different from hospitals. This study employs qualitative research method with a phenomenological approach. Data collection was carried out using the informant's perspective (emic perspective), and key instruments, such as observation, interviews, documentation studies, and questionnaires. Qualitative analysis is deployed as the data analysis in this study. The validity of the research findings was measured using the validity and reliability standards of qualitative research, namely: credibility, dependability, confirmability, and transferability. The findings showed that: nurses' service in preventing stunting like improving children's nutrition at UPT Puskesmas Astana Anyar Bandung is considered as quite good; this can be seen from the perceptions and expectations of patients using and receiving the service of stunting prevention.
\end{abstract}

Keywords: nurses, stunting, community health, service quality.

Received: 6 April 2020 ;

Accepted: 8 June 2020 ;

Publish; December 2020.

\section{How to Cite:}

Hendra, A., Akbar, M., \& Sariwulan, T. Rd. (2020). Analysis of The Nurses Service in Preventing Stunting at UPT Puskesmas Astana Anyar Bandung. International Journal of Human Capital Management, 4 (2), 33-41. https://doi.org/10.21009/IJHCM.04.02.04 


\section{INTRODUCTION}

Research by researchers is very important to do considering the problem of stunting is rarely examined from the standpoint of management science. Stunting is a hidden tragedy. Stunting illustrates the chronic malnutrition status during the period of growth and development since the initial phase of life (Ni'mah \& Nadhiroh, 2015). This circumstance is presented by the z-score value of body height according to the age (BH/A) which is less than -2 of deviation standard (DS), WHO's growth standard shows (WHO, 2010). Globally, around 1 of 4 toddlers have stunting (UNICEF, 2013).

Family defence becomes the main pillar in preventing and handling stunting. The efforts would result in the prevention of failure in the growth and development of children under five years old, which may be possible due to the chronic malnutrition. Law Number 52 Year 2009 defines family defence and welfare as the family condition which has tenacity and resilience, and it contains material physical ability for independent life and self- and family development to live harmoniously in improving physical and emotional welfare and happiness. Furthermore, the family defence is indicated as adequate and continuous access to income and resources, at least to meet ends need, including adequate access to food, water, health services, education, housing, time to participate in the society and social integration. Hence, family defence is a pillar of stunting prevention and handling in the society.

The initial survey conducted by the researchers through the interview with the community health centre's (puskesmas) staffs and patients shows optimal citizens satisfaction to the nurses' service in preventing stunting. This optimal service is seen can be seen through the professionalism of health workers, the quality of paramedic human resource which has been improved through various trainings, the complete medical utilities, the good health service tools, and the strength of the puskesmas' management. This study focuses on the nurses' service in preventing stunting at UPT Puskesmas Astana Anyar Bandung. The sub-focuses of this study include: a) The performance of nurses in conducting tasks to prevent stunting, b) The cause factors of the good and bad nurses' service in stunting prevention, c) The strategy to improve nurses' service in stunting prevention, and d) The quality of health services given by the nurses in stunting prevention.

\section{LITERATURE REVIEW}

\section{Stunting}

Nutritional problem is one of the problems in lifespan, starting from pregnancy, babies, toddlers, adolescents, to the elderly. Nutritional problems can occur in any age range, even nutritional problem in a certain age group would affect the nutrition status within the next life cycle (intergenerational impact) (Mitra, 2015). A child who has stunting is more likely to grow as a short individual in the adult phase. If stunting is not handled properly, a newborn with low weight will keep existing in the next generation, thus creating the problem of intergeneration short children (UNICEF, 2013).

Malnutrition problem 1000 HPK starts from the slowing down or retardation of the fetus growth or known as IUGR (Intra Uterine Growth Retardation). In developing countries, the malnutrition during pre-pregnancy and pregnancy period affects the birth of babies with IUGR or BBLR. IUGR condition is almost partially related to the nutrition status of the mother, which are body weight (BW) of pre-maternity that is incompatible with the mother's height or having a short posture, and the increase of body weight during the pregnancy $(\mathrm{PBBH})$ that is less than the standard. A mother with short posture when she was two years old is more likely to have short posture when she is entering the adult phase. In her pregnancy, a mother with short posture will likely bear a baby with BBLR (Victoria et al., 2008). If there is no improvement, IUGR and BBLR will keep occurring in the next generation, thus creating the problem of intergeneration short children. 
Research of basic health (Riskesdas) showed increasing prevalence of stunting in Indonesia from $36.8 \%$ in 2007 to $37.2 \%$ in 2013; in another word, 1 from 3 children in Indonesia is categorised as short (Riskesdas, 2013). Stunting problem is a nutritional problem faced by the world, especially in developing and low-income countries. Stunting is a failure in growth due to the accumulation of ever-occurring malnutrition from the pregnancy until the age of 24 months. Toddlers under three years old with stunting and short posture will have them until their five-yearold period. Adult women with stunting are more likely to have babies with low body weight when they are born. Stunting can occur in intergeneration if the right intervention is not conducted since the early stage.

\section{Influential Factors to Stunting}

Stunting is influenced by multidimensional factor and not only by malnutrition factor experienced by pregnant woman or toddlers. Thus, the most determining factor to prevent the prevalence of stunting must be done during the first 1000 days of life (HPK) of a toddler. In more details, several influential factors to stunting are 1) the bad practice of nurturing; 2) the limitation of health services including ANC-Antenatal Care (health service for mother during pregnancy), Postnatal Care, and quality early lesson for pregnant woman; 3) the lack of access to nutritional foods for households/families; 4) the lack of access to water and sanitation; 5) Diseases that the child has, such as acute respiratory infections and diarrhoea which often experienced by children; 6) inadequacy of the family's economic status; 7) educational status of the family; 8) inadequate environmental health; 9) inadequate healthcare; 10) inadequate behaviour in doing PHBS (clean and healthy life behaviour); 11) decreasing reproductional health, and 12) the lack of food availability.

A research conducted by Senbajo et al. (2011) showed that influential factors to stunting are public schools, polygamous family setting, inadequate knowledge of the mother and low social status. From those four factors, inadequate knowledge of the mother is the most influential factor to children with stunting. Nonetheless, Assefa (2013) noted that the socioeconomic status of the family, age, sex and knowledge of the mother are the most important factors of the child's nutritional status (underweight and stunting).

The Board of National Development Planning (Bappenas) in the notice written in the Policy Framework of National Movement for the Acceleration of Nutrition in accordance to $1000 \mathrm{HPK}$ (1000 HPK Movement) explains that stunting in 1000 HPK is the impact of several interrelated factors. There are two direct factors that influence an individual's nutritional status, namely food and infectious disease; both are influential to each other. The first direct influential factor is food consumption that does not go along the principle of balanced nutrition. The second one is an infectious disease related to the prevalence of transmitted diseases and bad environmental health.

The first direct influential factor is the consumption of food that does not meet the amount and composition of nutrients in the perspective of balanced nutrition (i.e. diverse, as needed, clean and safe), such as a baby that does not get exclusive breastfeeding. The second direct influential factor is the infectious diseases pertaining to the prevalence of the occurrence of transmitted diseases, especially diarrhoea, ascariasis and acute respiratory disease. These factors are often related to the quality of basic health services, especially immunization, environmental quality and healthy behaviour. The environmental quality especially includes the availability of clean water, sanitation means and healthy behaviour, such as the habit of soap hand-washing, pooping in the toilet, not smoking, air circulation in the house, and many more.

\section{Community Health Services}

This research studies health services as an integral part of public services, the area of which the civic workers as the state apparatus work in the government institution to provide services to the society. 
Quality of the services is the key to an organization's excellence, including the government institution, within the increasingly competitive era nowadays. Fitzsimmons (2015) notes five aspects of the quality of the services, which include:

1. Tangibles covers the outlook of the physical facility, equipment, workers and communication tools.

2. Reliability covers the ability to provide convincing and precise guaranteed services.

3. Responsiveness covers the eagerness to help customers and provide fast services.

4. Assurance covers the knowledge and hospitality of the workers and their ability to convince and trust.

5. Empathy covers personal attention.

Service quality contains consumer expectation and perception towards the service (customer perceived quality) and the comparison between them. Ideally, service quality is seen from the perspective of the consumer, not from the perspective of the service provider. Hence, from the explanation above, community health services hold a critical role in the development efforts to realize the quality of Indonesian people as a whole.

\section{Community Health Centers (Puskesmas)}

Puskesmas is the front-row unit of a health service organization with the mission as the development centre of health services, which conducts overall and integrated health training and services for the society living in a certain work region.

Based on the description, community health centres, which are given by the government through the civic workers for the community, are one of the scopes within state administrative duties to improve the quality of health services given to the society, including the patients.

\section{Nurses}

Nursing is a form of professional health service in fulfilling the human's basic needs (biological, psychological, social and spiritual) which is given to an individual, a family, a community in health and sickness (Hidayat, 2011).

According to the description above, it is synthesized that a nurse is someone who graduated from the nursing education and has the ability and the right to conduct nursing activities based on the academic discipline. A nurse also provides health services holistically and professionally to healthy and sick individuals. A nurse is obliged to fulfilling the patients' bio-psycho-social and spiritual needs.

\section{Service Quality}

Albrecht and Zemke (as cited in Dwiyanto, 2005) argued that public service quality is a result of the interaction of various aspects, namely service system, human resource of service provision, strategy and customers. Hence, service quality is the characteristic totality of a service concept encompassing all service aspects, and the measurement of service quality is providing satisfaction to the customers. 


\section{Research Framework}

The research framework is as seen in the figure below.

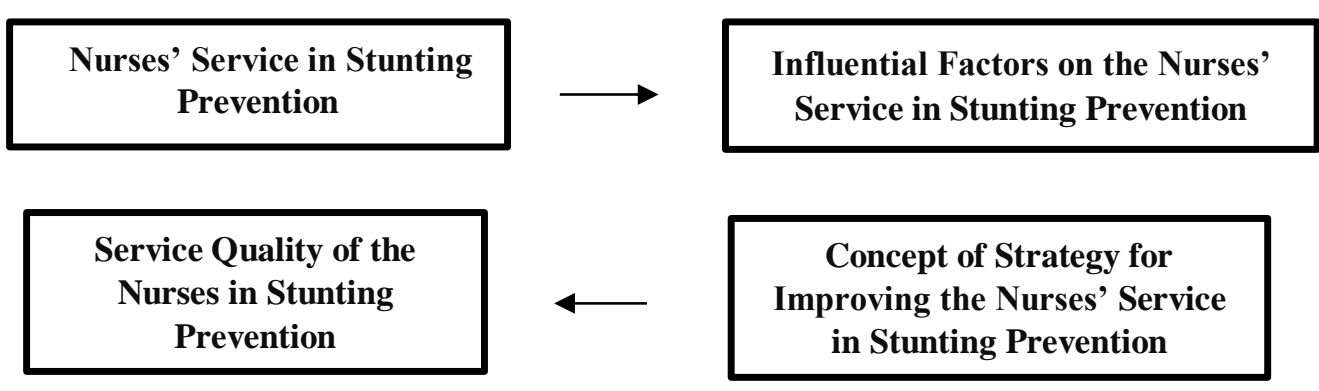

Figure 1 Research Framework

Systematically elaborated, the explanation of the variables analyzes:

1. Nurses' service in conducting stunting prevention in Puskesmas.

2. Influential factors on nurses' service in stunting prevention in Puskesmas.

3. A new concept in the form of strategy model for improving nurses' service in stunting prevention in Puskesmas.

4. Quality of health services given by the nurses to prevent stunting in Puskesmas.

\section{RESEARCH METHOD}

This study employs qualitative research method with a phenomenological approach to analyse and formulate the nurses' service improvement in stunting prevention in Puskesmas. This study aims in: a) Analyzing the nurses' service in stunting prevention in Puskesmas, b) Analyzing the influential factors on nurses' service in stunting prevention in Puskesmas, c) Analyzing the new concept in the form of strategy model for improving nurses' service in stunting prevention in Puskesmas, and $d$ ) Analyzing the quality of health services given by the nurses to prevent stunting in Puskesmas.

This study was conducted at UPT Puskesmas Astana Anyar Bandung, which is located in the work region of the Bandung Health Agency. The study was set out from April 2019 to August 2019. The researchers deployed case study to understand the research object. This case study research is supported by an analytical-qualitative descriptive method. The data that was collected from the research field can be categorized as the primary and secondary data. The informants in this study consisted of four people consisting of two nurses and two patients, among others in the table below:

\section{Table 1. Informant Data}

\begin{tabular}{clc} 
No. & \multicolumn{1}{c}{ Name } & Information \\
\hline 1. & Nani Setiani & Nurse \\
\hline 2. & Hanifah Pratami & Supervisor Nurse \\
\hline 3. & Acep Supriatna & Patient \\
\hline 4. & Yusuf Wahyudi & Patient
\end{tabular}

Questions asked by the researcher to the nurse:

1. In the nursing process, there are five stages: (1) assessment, (2) health diagnoses, (3) planning, (4) implementation, and (5) evaluation. Can you explain these stages in carrying out your duties as a nurse? 
2. Related to the four main tasks of nursing, namely (1) providing nursing care, (2) managing nursing services, (3) carrying out guard and standby tasks, and (4) carrying out specific tasks. Can you explain the four main tasks?

3. Regarding the strength or health care advantages from the point (1) the behavior of the patient/community, (2) government policy, (3) health clinic facilities, and (4) the quality of Human Resources nurses. Can you explain this?

4. Regarding the problems or weaknesses of health services from the point of view as previously asked, namely (1) patient/community behavior, (2) government policies, (3) health center facilities, and (4) the quality of Human Resources for nurses. What do you think of the problem or weakness?

Questions asked by the researcher to the patient:

1. How the health services of health center to the community in carrying out their duties?

2. How care nurses to help patients in solving difficulties, whether the quality of health services at the health center has met the expectations of patients as recipients of these services?

The validity of the findings of this study strives to meet the criteria or standard of qualitative research validity and reliability, as Lincoln \& Guba (2015) notes: credibility, dependability, confirmability and transferability.

\section{RESULT AND DISCUSSION}

Based on the research findings, it is found that overall, toddlers' nutritional status, according to the patients' visit, almost every toddler gets good nutrition (87.9\%). However, the finding shows $10.6 \%$ of toddlers have bad nutritional status or malnutrition. From the indicator of BW/A and $\mathrm{BH} / \mathrm{U}$, it is found that more than half of toddlers have normal height/weight $(73.1 \%)$, and $23.8 \%$ of toddlers have a short and extremely short figure.

Social status of the family, such as economic status and educational background of the mother, influences stunting on children. Low level of knowledge that is possessed by the mother can result in stunting on the children. The factors that may be influential on stunting in this study include low educational background of the mother, the age of the mother which is mostly in the category of late adolescence, the family income that is less than UMR, and bigger expense average of the family compared to the family income; there is a small population of the mothers who have malnutrition. The findings are in line with the study conducted by Samba et al. (2016), which found that family poverty and bad family health are closely related to stunting. UNICEF (2006) reported that there is a close relationship among the children's nutritional status and the poverty, the mother's nutritional status, and the mother's ability to make a decision (women's decisionmaking power). The family's economic status is one of the influential factors to stunting on the children.

Stunting is more likely to happen in a poor family. Families with low income are exposed to the risk of food and nutritional insecurity, which is the result of the family's low ability to provide food resources, low educational status of the family, limited access to information on nutrition, and bad access to health services. This study found that nearly almost families have an income lower than IDR 1.500.000, even lower than the West Java's UMR (IDR 2.550.000, and the family's expense is higher than the income, thus the money used for buying food exceeds the family's purchasing power. Aside from directly related to food availability, poverty is also related to the low ability of the family to provide clean water, good health hygiene, healthy toilet and healthy housing. These aspects are indirectly influential to the risk of stunting on the children.

In this study, most children are nurtured by the housewife with secondary education. In developing countries, especially in the case of mothers with low education, a mother has not taken part in the family's decision making, including in the nutritional and health maintenance; she does not have direct access to the resources for the children's nutritional provision. This is related to the family's hardship in the economy, so every expense has to go under the husband's acceptance, 
including for food buying as the main resource of the children's nutrition. This study also found that there is a small population of mothers who have malnutrition history during the pregnancy. The mother's nutritional health status is influential to stunting on the children, so it is obligatory for the mother's status condition to be good during the pre-pregnancy and the pregnancy, even long before the pregnancy (i.e. school-age and adolescent phase). Hence, the mother's nutritional health status is supposed to be on the normal condition.

Aside from quantitative data collection, this study also deploys qualitative method by conducting interviews and focus group discussion to obtain the illustration on Tri Bina program, especially Bina Keluarga Balita (Toddler's Family Development/BKB) in strengthening the family defence to prevent stunting on the children. Some probing questions that were asked include the stakeholder's knowledge on family defence especially Bina keluarga balita, the participation of PLKB's cadres and staffs, and the stakeholder's hope on program execution in the future. Generally, the result of analysis on the nurses' service in stunting prevention at UPT Puskesmas Astana Anyar is described below.

1. Bina Keluarga Balita Program

Bina Keluarga Balita (BKB) Program is one of BKKBN's most superior programs -- an activity that especially manages the development of children's growth and development through the right nurturing pattern based on the age group, executed by the cadre on the hamlet level. The program aims in improving the knowledge, creativity and awareness of the mother and the family members.

2. BKB Program Implementation

Society's response toward the ongoing BKB program is positive and enthused. BKB is implemented along with Posyandu, in which they are complementary to each other. In Posyandu, there is Kartu Menuju Sehat (KMS) or Health Card, and in BKB, there is Kartu Kemabng Anak (KKA) or Children's Development Card.

3. Challenges in BKB Program Execution

There are some challenges in the execution of $\mathrm{BKB}$, including inadequate facility, varied human resource (cadre), low incentives received by the cadre, and the number of people who find it difficult to attend the program due to the far distance and high level of activities.

4. Efforts in Tackling Challenges of BKB Program Execution

There is sincerity and awareness of the importance of BKB program, so sometimes personal funding is used to support it. The cadre makes efforts in visiting people who cannot attend to give motivation and look for the obstacles that make them absent.

5. Hopes for the Improvement on the Next BKB Program

The cadres hope that the government would give more budgets so that the service would improve along with the community participation.

6. Cadre's Participation in BKB Program

Almost every cadre actively participates in this BKB program

7. Cadre's Role in BKB Program

The cadre's role in BKB program is pivotal since the cadre directly interacts with the people, from socializing the program, inviting them to participate and giving them adequate knowledge and information.

8. Evaluation of Cadre's Role in BKB Program

The cadre has done their role efficiently on the field. However, it is important to note that cadre regeneration, knowledge development through various training or capacity building, and more reward in the form of better incentives are necessary since they motivate the cadre in working better and more aggressively.

Based on the explanation, it is found that the nurses, in preventing stunting, must support Bina Keluarga Balita program as a program to improve knowledge, attitude, behaviour and skills of the parents and fellow family members in nurturing and building the growth and development of the toddlers through physical stimulus, emotional, social, and spiritual intelligence through effective interaction between the parent and the child. BKB movement has to be supported by the nurses in building a partnership between the government and the society to maintain the children's 
health, the growth and development of the children, early detection on health problems, disability prevention, and preparation for toddlers to interact with the other children.

\section{CONCLUSION}

Based on the explanation above, the researcher draw some conclusions that will be presented in this paper, are as follows: 1) The nurses' service in stunting prevention at UPT Puskesmas Astana Anyar regarding their main duties and functions has run well, 2) Despite running well, the nurses' service in stunting prevention is not optimal due to the need of help from midwives since the nurse is not a midwife. Division of duties, functions, activities and performance standards that must be achieved by the nurses in Puskesmas tend to be formulated based on the program targets and not be adjusted the tasks that supposedly be carried out on the basis of the functional nurses' positions, 3) Influential factors on the success of the nurses' service in stunting prevention is hugely supported by the health agency's work plan, policy or action planning and budgeting so as being able to empower all the potentials of nurse resources, and 4) Strategies for improving the nurses' service in stunting prevention is generally grouped into two categories, namely training strategy and non-training strategy (motivating and improving the condition of work environment or organizational situation). Bandung Health Agency programmed education and training albeit still very dependant to the state of the funds, not based on the need analysis. Improvement program for health services has helped its resources in cooperating together; the quality of facilities and infrastructure has been adequate and nice. Health services improvement provided by the nurses in Puskesmas includes promise-keeping, attention, service provision since the arrival time of the patients, proper service, and error avoidance in taking notes.

\section{Recommendation}

For recommendations or suggestions based on the discussion and conclusions above, the researcher provides several recommendations, are as follows:

\section{Academic Recommendation}

It is difficult to discover studies with the focus on the nurses' service in tackling the problem of stunting either in the form of a research report or academic paper, compared to the studies on human resource management. Hence, here are some academic suggestions pertaining to the nurses' service in tackling the problem of stunting to enrich the future research in collecting more comprehensive and accurate findings.

Studies on the nurses' service in this research is still limited to analyzing the nurse performance qualitatively, which is focused on the service of stunting problems in Puskesmas, including the field of nursing service duties, community service, professional development and supporting nurses' service.

The cause of the nurses' service in handling stunting needs to be analyzed from the factor of ability and effort/motivation possessed by the nurses (internal) and the condition of work environment or organizational condition in Puskesmas (external) using the theory of attribution from Dale Timple.

Improvement strategy on the nurses' service in handling stunting problem needs to be based on the training and non-training strategy.

The analysis of health service quality conducted by the nurses in handling stunting in Puskesmas, needs to be focused on the aspects of tangibility, reliability, responsiveness, assurance and empathy as the reference.

\section{Practical Recommendation}

Several practical suggestions for the performance improvement of the nurses in providing service of stunting problem handling in Puskesmas are as follows:

It is necessary to develop the knowledge of nurses and cadres through various training and coaching to not only provides insights regarding the children's growth and development, but also 
how to deliver information effectively to the toddler's family. Selection of the cadre should consider the commitment and motivation to develop social welfare. Furthermore, after the commitment and motivation are developed, the government should consider giving more rewards to the cadre in the form of better incentives to be taken as a trigger to work harder and better. Regeneration of cadres is needed, and regular monthly meeting of all cadres should be conducted to learn the obstacles in the field and formulate the right solution to tackle them.

The sectoral partnership should remain and be improved to develop the children's growth and development. The cross-sectoral partnership to be conducted by the Ministry of Agriculture, the Ministry of Cooperatives and the Ministry of Home Affairs is to improve food and nutritional defence through the Program of Food and Nutritional Defence. The conducted activities may be in the forms of a) Ensuring food access that fulfils nutritional needs, especially for pregnant women, breastfeeding mothers, and children; b) Ensuring optimal utilization of food available for all classes of the population; c) Providing more attention to the small farmers, fishermen, and gender equality; d) Micro Economic Empowerment for Families with mothers experiencing lack of protein-energy (Kurang Energi Protein/KEK); e) KB Service Improvement.

\section{REFERENCE}

Colquitt, J.A., Lepine, J.A., \& Wesson, M.J. (2009). Organizational behavior: Improving Performance and Commitment in the Workplace. McGrawHill.

DepKes, R. I. (2011). Pedoman pelaksanaan kewaspadaan universal di pelayanan kesehatan.

Fitzsimmons. (2015). Delivering Quality Service: Balancing Customer Perceptions and Expectations. In V. R. Zainal, et al., Manajemen Sumber Daya Manusia Untuk Perusahaan. Jakarta: Rajawali Pers.

Kuntjoro, T. (2007). Standar pelayanan minimal rumah sakit sebagai persyaratan badan layanan umum dan sarana peningkatan kinerja. Jurnal Manajemen Pelayanan Kesehatan, 10(01).

Lincoln, Y. S., \& Guba, E. G. (2015). Naturalistic Inquiry. In Sugiyono, Memahami Penelitian Kualitatif. Bandung: Alfabeta.

Mc Clelland, D. C. (2005). The Achieving Society. New Jersey: D. Van Nostrand Company. Inc.

Rajagukguk, T. (2017). Pengaruh Perilaku Organisasi Terhadap Prestasi Karyawan Pada PT. Perkebunan Nusantara II (PERSERO) Medan. Jurnal Ilmiah METHONOMI, 3(2), 124-137.

Robbins, S.P, \& Judge, T.A. (2014). Perilaku Organisasi. Jakarta: Salemba Empat.

Subekhi, A., \& Jauhar, M. (2013). Pengantar Manajemen Sumber Daya Manusia. Jakarta: Prestasi Pustaka.

United Nations Children's Fund (UNICEF). (2013). Improving child nutrition: The achievable imperative for global progress.

UNICEF Indonesia, (2013). Ringkasan kajian gizi ibu dan anak.

UNICEF . (2000). Strategy for Improved Nutrition for Women and Children in Developing Countries.

UNICEF. (2013). Improving child nutrition, the achievable imperative for global progress. New York: United Nations Children's Fund.

UNICEF. (2012). Ringkasan kajian gizi Oktober 2012. Jakarta: UNICEF Indonesia. USAID. (2014). Multi-sectoral Nutrition Strategy 2014-2025 Technical Guidance Brief: Implementation Guidance for Ending Preventable Maternal and Child Death, 1-6. 